\title{
IN HONOUR OF PROFESSOR IVAN VAKARCHUK ON THE OCCASION OF HIS 60th BIRTHDAY
}

6 березня 2007 року відомому українському вченому професору Іванові Вакарчуку виповнилося 60 років. Іван Вакарчук народився в селі Старі Братушани, Єдинецького району в Молдові. У 1970 році закінчив фізичний факультет Львівського державного університету імені Івана Франка. По закінченні аспірантури у відділі Інституту теоретичної фізики АН УРСР захистив кандидатську дисертацію на тему "Застосування методу зміщень і колективних змінних до дослідження системи взаємодіючих бозе-частинок" під керівництвом академіка Ігоря Юхновського. У 1980 році, захистивши дисертацію "Мікроскопічна теорія бозе-рідини", Іван Вакарчук став одним із наймолодших докторів наук та очолив відділ квантової статистики Львівського відділення ІТФ АН УРСР. Від 1984 року дотепер професор Вакарчук - завідувач кафедри теоретичної фізики Львівського університету, а з 1990 - його ректор.

Професор Вакарчук є не лише відомим ученим, але й організатором науки, педагогом, громадським діячем. Зважаючи на профіль нашого журналу, ми зосередимося на його наукових здобутках.

На фоні традиційної в сучасній науці вузької спеціялізації професора Вакарчука вирізняе широта наукових інтересів: фізика квантових рідин, у тому числі теорія надплинного гелію-4, теорія фазових переходів та критичних явищ, фізика невпорядкованих систем, фізика магнетних систем, математичні методи в теоретичній фізиці, фундаментальні проблеми квантової механіки та квантова інформатика, геофізика, загальна теорія відносности та космологія, теорія зоряних спектрів, філософія науки. У кожній із цих ділянок він запропонував нові оригінальні підходи до вивчення різноманітних фізичних явищ і процесів. Широта наукових зацікавлень дозволяе професору Іванові Вакарчуку застосовувати методи, які він створив для дослідження одних явищ, до інших. Для багатьох задач таке, на перший погляд, несподіване, застосування виявляється надзвичайно ефективним. Його наукові дослідження вирізняє першопринципний підхід, що полягає у формулюванні проблем на основі фундаментальних рівнянь із наступним доведенням результатів теорії “до числа".

Один із важливих напрямків його досліджень пов'язаний із теорією квантових рідин, зокрема 3 теорією надплинного гелію. Особливістю мікроскопічної теорії квантової бозе-рідини, яку він побудував, є те, що в ній уперше послідовно й коректно враховано внесок три- та чотиричастинкових кореляцій - це забезпечило кількісний опис властивостей рідкого гелію. У 1970-х роках Іван Вакарчук запропонував новий метод розрахунку статистичних матриць густини, на основі якого вдалось уперше побудувати кількісну теорію явища бозе-айнштайнівської конденсації в надплинному гелії, результати якої підтвердили експериментальні вимірювання. Знайдено також нове зображення для статистичної суми у вигляді функціонального інтеграла за звичайними змінними для багатобозонних систем та за твірними алгебри Грассмана для багатоферміонних. Вивчено властивості фермі- і бозе-рідин у ділянці низьких температур та в околі точки фазового переходу до надплинности.

Дослідження структурних та термодинамічних властивостей гелію при низьких температурах привели Івана Вакарчука наприкінці 1970-их років до ще однієї важливої й важкої задачі - аналізу $\lambda$-переходу в гелії-4. 1970-ті роки - це час, коли завдяки поєднанню методів і концепцій квантової теорії поля та статистичної фізики була створена ренормгрупова теорія фазових переходів. Ця теорія не лише пояснила унікальні властивості матерії в околі критичних точок, але й дозволила отримати з високою точністю значення різних величин, що характеризують критичну поведінку. Ланкою, що поєднала попередні дослідження Івана Вакарчука із задачами теорії фазових переходів, став його розв'язок рівняння Блоха для статистичного оператора багатобозонної системи. Застосувавши представлення когерентних станів, учений записав термодинамічний потенціял багатобозонної системи у вигляді функціонального інтеграла, який відтворював модель $\varphi^{4}$ теорії поля і, природно, приводив до ренормгрупового аналізу. Почавши з аналізу $\lambda$-переходу й запропонувавши оригінальне рівняння ренормгрупи для опису цього переходу, Іван Вакарчук перейшов до аналізу критичної поведінки ширшого класу систем із багатокомпонентним параметром порядку. Методологічна важливість цих робіт полягала ще й у тому, що в них використано традиційну для теорії поля теорію збурень за константами зв'язку. Саме ж рівняння ренормгрупи отримано за допомогою наближеного перетворення, яке раніше запропонував академік 
Юхновським. Традиційно в цьому методі використовували розклади за оберненими константами зв'язку - подібний підхід у 1990-х роках дістав назву непертурбативного. Таким чином, роботи проф. Вакарчука проклали місток між пертурбативним та непертурбативним підходами в теорії фазових переходів.

У 1980-х роках у межах формалізму функціонального інтегрування Іван Вакарчук з учнями запропонували новий метод розрахунку функцій Гріна та кореляційних функцій для багаточастинкових систем. Цей метод грунтується на тотожностях для функціональних інтегралів, які він запропонував, і на розв'язку ланцюжка рівнянь для середніх від добутків функціональних змінних і дає змогу обійти проблему явного розрахунку функціональних інтегралів. На основі такого підходу досліджено квантову модель Гайзенберґа, класичні рідини з урахуванням далекосяжних і короткосяжних взаємодій та інші системи. У той же період він розпочинає також активне вивчення невпорядкованих спінових, електронних та фононних систем. Астрофізичні дослідження професор Іван Вакарчук проводить із початку 1980-х років. Вони головно стосуються квантової теорії переносу випромінювання в зоряних атмосферах.

Із перших принципів на підставі розгляду елементарних процесів взаємодії фотонів з атомами та молекулами побудовано кінетичне рівняння для фотонів з урахуванням одно- та двофотонних переходів і на його основі знайдено нелінійне рівняння переносу для інтенсивности випромінювання в зоряних атмосферах $з$ явними першопринципними виразами для коефіцієнтів поглинання і так званих функцій перерозподілу за частотами. Іван Вакарчук побудував релаксаційну теорію ударного наближення для сталої загасання, що визначає лоренцівський внесок у формування контуру в спектральній лінії атома.

У 1990-х роках Іван Вакарчук створив новий математичний метод розрахунку властивостей багатобозонних систем, уперше знайшовши такі вирази для матриці густини та термодинамічних функцій квантових рідин, які при низьких температурах дають відомі результати теорії Боголюбова і відтворюють також результати автора, де враховано багаточастинкові кореляції, а при високих температурах переходять, без додаткових припущень, у відомі результати теорії класичних рідин. Саме ця самоузгодженість теорії дала змогу кількісно описувати такі тонкі фізичні характеристики, як теплоємність бозе-рідини в околі точки фазового переходу в надплинний стан. Уперше в межах одного підходу вдалося не лише з'ясувати математичний механізм творення неаналітичности термодинамічних функцій (точка фазового переходу), а й розрахувати, без будь-яких підгінних параметрів, з використанням як вихідної інформації рідинного структурного фактора криву "теплоємність-температура", яка кількісно узгоджується з експериментальними вимірами. Причому побудована теорія пов'язує між собою лише спостережувані величини і дає змогу контролювати наближення.

Теорія багатобозонних систем є постійним науковим зацікавленням професора Вакарчука. У 2000-х роках він запропонував новий метод розрахунку повної матриці густини та термодинамічних функцій багатобозонної системи і знайшов їхні явні вирази в наближенні парних кореляцій для довільних температур. Теорія $є$ самоузгодженою в тому сенсі, що обчислені фізичні величини при низьких температурах збігаються з відповідними виразами теорії Боголюбова, а при високих температурах приводять до результатів теорії класичного неідеального газу в наближенні хаотичних фаз і виявляють фазовий перехід як результат бозе-айнштайнівської конденсації, що здеформована міжчастинковою взаємодією. Усі остаточні формули записано лише через рідинний структурний фактор, який береться як вихідна інформація замість потенціялу взаємодії, і отже, зв'язують між собою лише спостережувані величини, що дає також можливість досліджувати таку сильнонеіднеальну систему, як рідкий гелій-4. Для квантової рідини, яка складається з бозе-частинок, отримано рідинні й магнетні рівняння стану та досліджено вплив зовнішнього магнетного поля на явище бозе-айнштайнівської конденсації.

Від кінця 1990-х років учений розпочав новий напрямок досліджень, пов'язаний з фундаментальними принципами квантової механіки - квантова механіка з деформованою алгеброю Гайзенберга, квантова інформатика, квантова телепортація, квантова криптографія, міждисциплінарні науки, які тепер бурхливо розвиваються. Прикладом такого швидкого реагування професора Івана Вакарчука на нові досягнення в науці є те, що він висвітлив їх уже у другому та розширив у третьому виданні свого підручника "Квантова механіка" (2004, 2007). У галузі філософії науки особливу увагу професор Іван Вакарчук надає таким напрямкам, як зв'язок між методами досліджень природничих та гуманітарних наук, проблема двох культур, виявлення спільних математичних механізмів, які “керують" явищами, що спостерігаються в гуманітарній та соціяльній сферах.

На сьогодні науковий доробок професора Івана Вакарчука становить близько 300 публікацій.

Редакційна колегія ЖФД, колеги-фізики бажають ювілярові міцного здоров'я, нових цікавих ідей та наукового довголіття! 